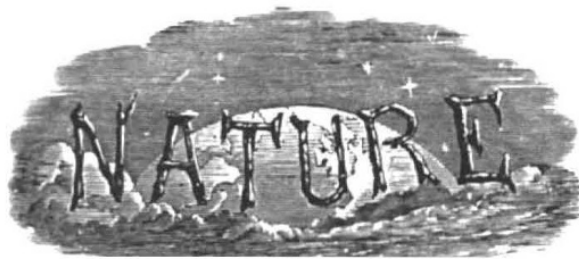

SATURDAY, DECEMBER 5, I93I.

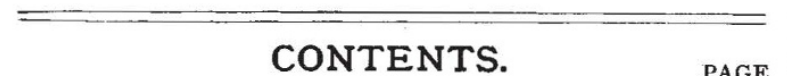

Science and Service

Progressive Biology. By Sir Frederick Gowland Hopkins, Pres.R.S.

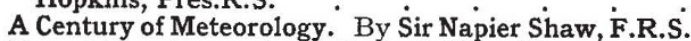

Recent Developments in Optical Glass Manufacture. By W. M. Hampton and W. N. Wheat.

Obituary :

Dr. S. W. Stratton. By Sir Richard Glazebrook, K.C.B., F.R.S.

Mr. Elsdon Best. By H. D. Skinner .

News and Views

Letters to the Editor:

Determination of the Yard in Terms of the Wave-length of Light.-J. E. Sears, Jr.; Dr. A. E. H. Tutton, F.R.S. .

Electron Exchange Phenomena in the Excited Atom.-Prof. R. Whiddington, F.R.S., and J.E. Roberts

The Atomic Weight of Fluorine.-Prof. E. Moles

Respiration of Healthy and Leaf Roll Potatoes. -Dr. T. Whitehead

Eurytemora thompsoni, A. Willey: A New European Record.-A. G. Lowndes Uteroverdin.-Dr. R. Lemberg, Prof. J. Barcroft, F.R.S., and Dr. D. Keilin, F.R.S.

Properties of Aerosols.-S. C. Blacktin

Carbon Contacts, - C. Turnbull ; C.V. Boys, F.R.S.

Electrical Conditions in Stratified Clouds. Dr. Michael Grabham

The Band Spectrum of AsH.-George E. Kimbal and John R. Bates

Branching of Lightning.-Major J. L.P. Macnair, R.A.

Esperanto in Scientific Literature.-R. M. MorrisOwen

Research Items

Astronomical Topics

.. .970

Anniversary Meeting of the Royal Society $\quad \cdot \quad \cdot 973$

The Wellcome Research Institution . . . . 974

Plant Breeding in Germany . . . . . . $\quad$. 975

University and Educational Intelligence $\quad \cdot \quad \cdot \quad \cdot \quad \cdot 975$

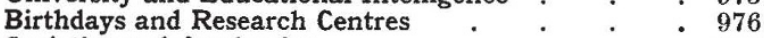

Societies and Academies . $\quad . \quad$. $\quad . \quad$. $\quad .977$

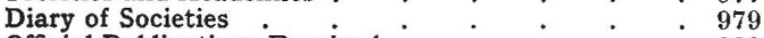

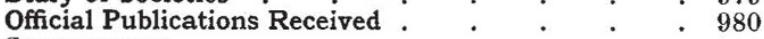

SUPPLEMENT.

A New Summary of Knowledge. By Prof. F. S. Marvin.

Topography and Tradition. By Prof. J. L. Myres, O.B.E.

History of Medicine

History of Demography

Animal Aggregations . . . . . .

Problems in Parthenogenesis. By Prof. A. D. Peacock

Agricultural Entomology. By Dr. A. E. Cameron

Researches on Fungi

General Stratigraphy. By J.P.

The New Surveying. By C. F. C.

Viscometry. By Emil Hatschek

Nature of Chemical Forces

Paper Making. By Dr. E. F. Armstrong, F.R.S.

The Teaching of Mathematics

Short Reviews.

No. 3240 , VoL. 128]

\section{Science and Service.}

THE universal interest aroused by the Faraday centenary celebrations in spite of the worldwide economic and political unrest well attests the power of scientific biography to arrest public attention when its human aspects are adequately stressed. Beyond question, the contrast between Faraday's humble beginnings as a bookbinder's apprentice and the revolutionary effect of his discoveries on industry and on society has profoundly stirred the public imagination. The immense benefits which society has derived from the researches of this prince of investigators, no less than his unflinching devotion to the pursuit of scientific truth for its own sake, apart from all utilitarian consequences, commanded the homage of the entire world of industry and science, and have manifested to thousands of others the worth and human interest of a scientific career.

There are, of course, innumerable other scientific workers whose lives and achievements, set out so as to reveal their forceful personality and the manner in which the restless, questing spirit of science enabled them to conquer obstacles and obtain, if not always their desired haven, at least some anchorage from which humanity could start its explorations afresh, are no less pregnant with human interest. Moureu, Pasteur, Rayleigh, Ross, Fabre-the brief memoirs we have of these and many others are aglow with inspiration for those who can sense the pulsation of their fateful thought as they wrestled with Nature for her secrets.

Nor is less human interest to be found in the lives of those scientific workers who have devoted their labours to industry. Much has been written in recent years regarding the dyestuffs industry, but the full romantic story of the development of that industry still awaits the chronicler who can weave the fragmentary pictures we have of Perkin wrestling with nitrobenzene at Greenford Green, Dr. Ter-Meer at Uerdingen, or Dr. H. Levinstein's own sketches of the early growth of his father's firm, into some vivid odyssey of industry. Possibly even yet we are too near to the field of action for this task to be attempted. The great combines of chemical industry, of which almost everywhere the dyestuffs industry now forms an integral part, are dynamic and not static, and by no means represent a final phase.

There is, however, a tendency, from which not even Dr. Levinstein appears to be entirely free, to regard the great days as past, and to consider the rationalisation of industry as synonymous with the 
departure of initiative and enterprise. To such an assertion, made even of the field of industry represented by the manufacture of dyestuffs, the careers of such leaders as Dr. Duisberg and Dr. Engi, to cite two alone, provide a remarkable answer. Both of these outstanding leaders of chemical industry entered the dyestuffs industry as research chemists, and both were responsible for brilliant discoveries in the dyestuffs field which contributed largely to the rapid development of their respective firms. To Duisberg's discovery of the benzopurpurins and of important intermediates like benzidine sulphone must be added that of numerous other dyestuffs for which the Bayer Company has become famous, as well as the discovery of phenacetin.

Duisberg's talents as investigator, however, were combined with a personality and a vision which not only resulted in his becoming in 1925 the head of the I.G. Farbenindustrie Aktiengesellschaft at Leverkusen, but also an outstanding leader in chemical industry, whose influence was felt in the whole organisation of scientific research in Germany, in the developments which enabled Germany to reconstruct her industries to meet the difficult situations arising in the post-War years, as well as in professional associations and the training of students for industry. Similarly, Dr. Engi's scientific genius, which gave the Society of Chemical Industry in Basle thioindigo and the halogenated indigoid and thioindigoid dyes of the Ciba series, was linked to organising powers and a personality which rapidly brought him to the head of the great Swiss firm.

Other examples might readily be found, but the career of the present chairman of Imperial Chemical Industries, Ltd., Sir Harry McGowan, who entered the service of the Glasgow branch of the Nobel Co. as an office-boy, and, in the United States, Dr. A. D. Little's creation of the largest industrial consulting organisation in the world, are all the further evidence that space permits us to adduce that, even in the present industrial conditions, romance is not dead, and that there is still scope for personality and originality.

The truth is that those who view the rationalisation of industry as involving the suppression of individualism and opportunism commit the ancient blunder of regarding industry and society as static and not dynamic, and are in the company of those who saw in the passing of mail armour, the stage coach, the sailing ship, the windmill, the end of decency and order. Even on its narrowest scientific and technical side, industry is constantly changing, and every technical advance tends to bring other changes which little by little bring new demands and confront industry with fresh problems of supply. So have the growth of the rayon industries and the lacquer industries made fresh demands on the dyestuffs industry, and the relation of these industries, and particularly the lacquer industry, to the development of the automobile industry is sufficient evidence of the rashness of attempting to prophesy the demands which will be made upon any industry two or three decades hence.

Apart from this technical aspect, rationalised industry itself offers a challenge to personality which is missed by many superficial observers. These see in the magnitude of the combine a security which they assume was not possessed by the smaller firms of a previous generation, and conclude that individualism and initiative will wither for want of stimulus. The very care with which the progressive rationalised undertakings provide for the welfare of their employees tends to blind these observers to the fact that size does not affect the dependence of the large combine for security upon the same law of service as the individual and smaller firms from which it has grown.

Rationalisation of industry is only a means to render more effective service under modern conditions, and such service will not be continuously rendered unless originality and personality find their full play in the direction of the large combine and ensure that its policy is not stereotyped but develops to meet the changing needs of the world. Service, not security, is the goal, and if prizes are greater in the larger enterprise, the possibilities and consequences attending a blunder in management can equally be more serious. New methods have to be elaborated, forecasting and planning to be attempted on a larger scale, and not even in these days can an adventurous spirit be diverted from the successful conduct of industry. The great prizes of industry as of life are never to the safe and prudent, but to the adventurous who are willing to sail the uncharted seas, who take risks and know that they take them. In the fields of industrial and economic co-operation which open before us to-day, in the planning of industry on a national and an international scale so as to avoid the recurrence of such depressions and economic crises as we are at present experiencing, no less than in the complex reactions of scientific discoveries and their technical applications, there is scope for man's noblest intellectual and moral gifts in securing control of his environment. 